\title{
Socio-Economic Implications of Housing Density Mix in Residential Estates of Akure, Nigeria
}

\author{
Enisan, O. F. \\ Department of Urban and Regional Planning, Federal University of Technology, \\ Akure, Ondo State, Nigeria \\ Prof. J. O.; Fasakin \\ Department of Urban and Regional Planning, Federal University of Technology, Akure, \\ Ondo State, Nigeria \\ Prof. J. O.; Basorun \\ Department of Urban and Regional Planning, Federal University of Technology, Akure, \\ Ondo State, Nigeria \\ Dr. Babajide Ojo, Department of Estate Management, Federal University of Technology, \\ Akure, Ondo State, Nigeria
}

\begin{abstract}
The socio-economic implication of housing density composition in residential estates is somewhat less straight forward. From the perspective of urban economists, the intra-urban location of forms, workers and households cause variation in the demand for housing and commercial space. The 2003 United Nation Report noted that by 2030 , about 60 percent ( $3 / 5$ of the world's population) will live in urban areas. In view of the attendant problems, the study focused on the socio-economic implications of housing density mix in residential estates of urban area using Akure, Nigeria as a case study. The study identified eight major socio-economic variables in eleven residential corridors of Akure to evaluate their impact on housing density mix. One estate was picked at random from the residential corridors for the study. 933 buildings were systematically selected for administration of questionnaires. For easy identification, maps were generated for each of the selected residential estates. The maps showed the buildings and roads, which were used in distributing and administering the questionnaire. It was observed that, the area was mainly dominated by civil servant with medium housing density development. Also, the degree to which socio-economic characteristics impacted housing density was positive with correlation coefficient $(r)=0.559$ and coefficient of determination $\left(R^{2}\right)$ of 0.312 . This implies that, socio-economic variables accounted for $31.2 \%$ of housing density in the area. The study suggested that government should introduce land use zoning to enhance effective land use planning and ensure proper housing density in the area.
\end{abstract}

Keywords: Socio-economic, Housing, Density Mix, Residential Development.

DOI: $10.7176 /$ RHSS/9-1-03

\subsection{INTRODUCTION}

In contemporary planning system, for sustainable and inclusive developments for current, emerging and future population, the concept of mixed density emerged. Cardew (2006) therefore defines mixed density as a residential development that contains a mix of housing types such as single dwellings and multi units and a collection of development forms such as size and height. Mixed density provides housing choice, which promotes a more diverse community and caters for diverse stages of life, maximizes infrastructure and land (Space management), and considers the provision of public transport system. Providing mixed density residential through a combination of low, medium and high densities is a commendable strategy of achieving sustainable housing for teeming urban population. However, a mixture of residential densities can also be accomplished within a mixed land use development. Development study by Gebel et al. (2005) revealed that mixed density is one of the built environment elements that contribute to high active transport, along with mixed land use planning and high connectivity.

Economists have been able to devise land price model as a function of distance across space to determine land rent and prices. In recent times, scholars from the circle of land economics have appraised the significance of residential land mix in urbanized world, among these is the study of (Neptis Foundation, 2014) in Canada that highlights the role housing type mix play in determining population density. They opined in the study that the impact of housing type mix on population density is facilitated by average household size. They further revealed that large average household size intensifies the impact of housing type mix on population density; while smaller average household size diminishes it. The study concluded that places with higher-than-average household sizes have higher population densities than constant household size. Chen, Guo and $\mathrm{Wu}$ (2011) explored the probable effects of rural-urban migration and urbanization on China's urban housing prices through her urban housing 
reform policy from 1995 to 2005. It is therefore crystal clear that existing literature from the gamut of economists and urban planners were silent on implications of housing density mix in residential estates of urban areas and the relationship between socio-demographic characteristics of land occupants regardless of means of ownership and density distribution. In order to bridge this literature gap, it therefore imperative to further the boundary of existing studies and focus on the socio-economic implications of housing density mix in residential neighbourhoods of a developing nation like Nigeria.

The phenomenal rise in population, number and size of urban areas over the past few years in Nigeria have manifested in the acute shortage of dwelling units. These had caused congestion, high rents, poor urban living conditions, and poor infrastructure services and indeed high crime rates (Ajanlekoko, 2011). At the micro-level, home ownership is one of the topmost priorities for most households and it incurs the largest single investment. This becomes very significant, when it is realized that per capital and real income in Nigeria have been on the decline. Housing densities are increasingly mixed in Akure, Nigeria due to the combination of many interrelated components which include: land price, infrastructure, building materials, policies, building regulations and more importantly, finance (Aribigbola, 2008; Olamiju, 2014). Land in housing densities is very important because of the huge financial requirement and scarcity in most urban centres of the country for housing production (Mehmet, 2009). The low density settlements typical of urban fringe or peri-urban areas result in the removal of frontier vegetation and consequent loss of biodiversity, convert agriculturally productive areas to less productive residential development, exacerbate the spread of weed and animal pests and increase energy consumption and infrastructure provision costs (Lewyn, 2012).

Ironically, a fast-growing city like Akure, while having more sprawl, possesses some advantages in those areas that are developed. The traditional assumption of employment being concentrated in a single center has become less tenable with the decentralization of commercial and industrial activity in most large urban areas (Ilechukwu, 2010). Although, the rapid physical development witnessed in Ondo State has been a boost to its economy, Akure, the state capital, also had to grapple with an array of environmental challenges arising from its growth which could be described as astonishing (Aribigbola, 2008). Some of the environmental challenges the state has to grapple with include; congestion and unplanned human settlement.

The movement of people to Akure township increases the pressure on existing housing facilities such as schools and health centres leading to congestion and mushrooming of unplanned settlements. The fact that the area witnesses an unprecedented population growth in the last decade with no corresponding development in infrastructure and housing has led to the development of housing sprawl in some parts of the city (Aribigbola, 2008). These are mostly noticed in areas like Isolo, Oke-Ijebu, Oritagun, Oke-Aro, Isinkan, Odo-Ikoyi, OkeEmeso, Idi-Agba, Ijoka. Another key challenge, is sprawl development arising from rapid population growth. Other major challenges include building strong institutional framework for policy formulation and implementation. Apart from these, there are also inadequate funds to sustain the delivery of public utilities and key services like water supply, solid waste management, environmental beautification and so on. Increasing rate of poverty among urban and rural dwellers and its implication on resource utilization / consumption vis $-\mathrm{a}-\mathrm{vis}$ energy, sanitation and above all paucity of reliable data for effective environmental planning and management are noticeable (Rotowa, 2014).

In summary, when expectations about future development potential are high, more land will be withheld for development, land values will be higher, and the densities in developed areas will be higher. More development will be done on less land, at higher prices, as the owners wait for higher expected returns from future development. From the foregoing, land price is one of the factors inhibiting appropriate density mix in Nigeria residential areas to which little or no attention is given in recent studies (Olamiju, 2014; Owoeye, 2016; Gabriel, 2017). This study therefore, focuses on the effect of land prices on density composition in residential estates of Akure, Ondo State, Nigeria.

\subsection{THE STUDY AREA}

Akure is a traditional Nigerian city and like other traditional Yoruba towns in the country, it existed long before the advent of British colonial rule in Nigeria. The city situates in the South Western part of Nigeria (figure 1). Akure locates between Latitudes $7^{\circ} 15^{\prime}$ and $7^{\circ} 17^{\prime}$ North of the Equator and between Longitudes $5^{\circ} 14^{\prime}$ and $5^{\circ} 15^{\prime}$ East of the Greenwich Meridian (Rotowa, 2014). Akure was a medium- sized urban centre which became the provincial headquarters of Ondo province in 1939. It became both the capital city of Ondo State and Akure Local Government Council Headquarters in 1976 (figure 2). Consequently, there was heterogeneous massing of people and activities in the city. 


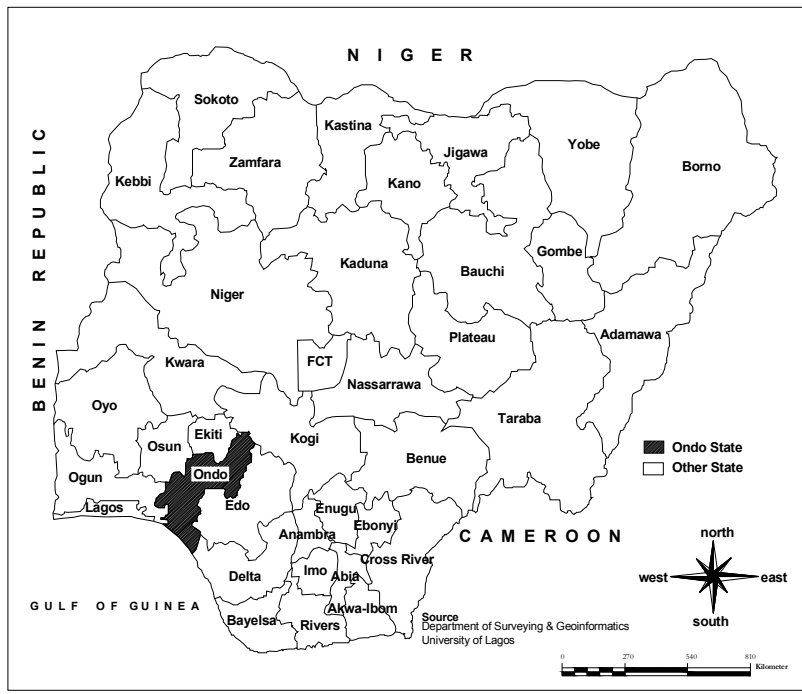

Figure 1: Ondo State in the Context of Nigeria

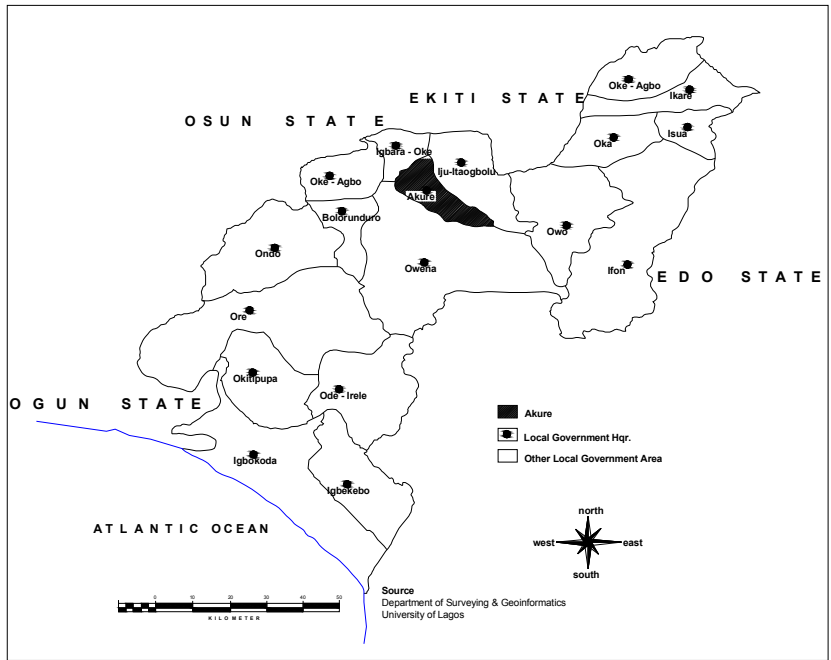

Figure 2: Akure in the Context of Ondo State

Source: Department of Urban \& Regional Planning, Federal University of Technology, Akure, 2016

The population of the city grew from 38,852 in 1952 to 71,106 in 1963 . Its population was estimated to be 112,850 in 1980 and 157,947 in 1990 (Ondo State of Nigeria, 1990). The 1991 national population census put the population of Akure at 239,124 and its estimates for 1996 was 269,207 (NPC, 2007). According to the 2006 National Population Census, the population of Akure was estimated to be 360, 268. This was projected to 2015 using 3.2\% growth rate. In 2015, the population was 457, 095 inhabitants. Akure as a city experienced environmental challenges in the area of pollution, waste disposal and sanitation. Environmental issues is expected to be a major challenge in foreseeable future as the city continues to grow in population, together with the expected rapid industrial growth.

\subsection{REVIEW OF LITERATURE}

\subsection{Residential density development}

Residential Density is used as a measurement of the spatial concentration of populations. There are a number of definitions of residential density within urban areas. Definitions used in the analysis of settlement densities in Sydney's urban areas (Cardew, 1996) range from site density to metropolitan density. The National State of the Environment report defines the concept as the area of land within urban centres designated 'residential land use' divided by total population of resident in those centres (Newton et al., 1998). For over some years ago, Nigerian government has campaigned for housing for all that meet human needs and aspirations. From the early Garden Cities to the post-Second World War new towns, the government consistent ideal has been medium-density housing in planned settlements with a sense of community and good access to jobs, shops, schools, services, and transport. It has constantly resisted sprawling, unplanned, low-density 20th-century sub urban development (Newman \& Jeffrey, 1999). The human settlement environment is strongly influenced by density. Both high density and high per capita land consumption rates associated with low class can have negative environmental consequences. Higher settlement densities bring pollutants to the urban environment; it also reduces the impact of residential development on surrounding ecosystems, productive agricultural resources, and reduces energy resource use (Duncan, 2008).

\subsection{Urbanization and land prices}

Cities are the main focus of land problems and the threshold population for their classification varies from one country to another and over time, even within the same country. More critical than population, is the function a metropolitan area performs. One of the distinguishing characteristics of a metropolitan area is that, its work is largely divorced from soil related activities, that is, its people are dominantly not primary food producers. Furthermore, it is unrealistic in Nigeria to classify all cities as metropolitan areas because of their peculiar functions. However, their roles as development advances in most instances result in increase in land value which affects housing delivery (Shulz \& Wereatz, 2004). According to the Bid Rent Model, land value increases as one moves towards the city center; and tend to be lower towards the urban fringe. But this theory does not apply in most parts of Akure. Some urban fringe increase, that is because of the complexity of cores or Central Business District (CBD) in value as we tend to move towards urban fringe as a resulted of several factors. One of these is to avoid the congestion and noise effects of the urban center. The rate at which people move from the core to the periphery also accounted for this (Nwaka, 2005). Unfortunately, the private sector is saddled with numerous 
problems which make supply always fall far short of demand and lower production quality (Nubi, 2008). The problem of qualitative housing has been a concern for both the government and individuals. Appreciating these problems, both public and private sector developers make effort through various activities to bridge the gap between housing supply and demand, but the cost of building materials, deficiency of housing finance arrangement, stringent loan conditions from mortgage banks, government policies amongst other problems has affect housing density mix significantly in Nigeria (Raji, 2008). With different policies and user solutions that are abound for the purpose of reducing quantitative housing deficiency. It could be possible to solve the problem if housing were used only for shelter needs. However, in addition to serving as a shelter, housing is also a produced commodity, consumer good, assurance for families, means used for reproducing social relations and an investment tool protecting the value of money against inflation (Omole, 2001). Moreover, it is important that house is a building block in its relations with its environment, mutual interaction and increasing the quality of its environment when it is considered as a part of the city. In this context, it can be accepted that a large housing stock is available today as a result of new presentation forms and production processes with a high volume of housing production. However, the existence of this stock shows that the housing policies were planned depending mostly on production. The informal private sector; in Akure comprising people of different income background resorted to self-help housing strategy. This sector has taken the risk of buying untitled land from informal market dominated by cabal popularly referred to as "Omo-Onile". This effort is more pronounced in areas like Odanikin-Ajimokun, Ilupeju, Asafinrin, Ifelere, Oke-Ogba, Oke-Odu and many other suburb of the town (see table 1). After the purchase of the land, majority of these people will take it upon themselves to construct their own roads, provide water and extend electricity for kilometers to make the house habitable. Lager percentage of housing supply in Akure recently is from this sector with the resultant effects of lack of standardization and distorted urban planning system.

Table 1: Residential development corridors in Akure

\begin{tabular}{cllc}
\hline Corridor Label & \multicolumn{1}{c}{ Name of Corridor } & \multicolumn{1}{c}{ Location } & No of Layouts \\
\hline A. & Obele-Ireakari & Ijare Road & 33 \\
B. & Odanikin-Ajimokun & Irese Road & 12 \\
C. & Ughele-Emure Camp & Ado/Owo Road & 33 \\
D. & Adesida-Oodo & Igbatoro Road & 3 \\
E. & Oladigbo-Jigba & Oda Road & 136 \\
F. & Asafinrin-Isafinrin & Idanre Road & 192 \\
G. & Fagbamila-YeostaAlphine & Ondo Road & 92 \\
H. & OkeOgba-OgunleyeOladogba & Agagu Road & 3 \\
I. & Ilupeju-Ifelere & Awule Road & 103 \\
J. & Alaba-Apatapiti & FUTA Road & 6 \\
K. & Zion-Wesco & Ilesa Road & 180 \\
& Total & & $\mathbf{7 8 7}$ \\
\hline
\end{tabular}

Source: Adapted from (Olamiju, 2014) Micro management issues in private residential layout Akure, Nigeria. Pp. 23

\subsection{METHODOLOGY}

Eleven Residential corridors were identified in the study area. One residential estate was selected from each of the eleven residential corridors in Akure (Olamiju, 2014). These were; Osolo-Abibiri Estate along Irese Road, Obele Estate along Ijare Road, Wesco Estate along Akure- Ilesha Express Way. Others were; Alaba Layout in Aule Area, Aloba Estate along Ondo Road, Ademola Adesida Estate in Alagbaka, Ifelere Estate in Aule, IreAkari Estate in Orita Obele, Gbeleaje Estate along Akure-Benin Express Way, Adedeji Estate along Ado Road and Oke-Ogba Estate along Agagu Road for sample survey. The eleven estates were chosen, because they had peculiar characteristics with the other estates along their corridor. These include: development patterns; socioeconomic characteristics; age of development; locational characteristics; among others (Figure 3). These estates were chosen using the simple random sampling technique. The questionnaires were administered systematically on household heads in the selected residential neighbourhoods. The simple random sampling technique was also used to pick houses and plots as well as the estate selected along the residential corridors.

The questionnaire was administered to collect data on the socio-economic characteristics of respondents and its implications on housing density mix. Building population from the 2006 Housing and Population census was used to obtain the number to be sampled. According to the National Population Commissions, buildings extracted through goggle map and ground truthing from the study area showed that, there were 9, 331 buildings within the selected estates. For easy identification, maps were generated for each of the selected residential estates. The maps showed the buildings and roads, which were used in distributing and administering the questionnaire. The first house was picked at random before systematically administering the question at an interval of 10 , until the required sample was obtained for all the residential neighbourhoods in the study area. In 
distributing the questionnaire, 933 household heads were sampled from the eleven residential neighbourhoods in Akure as shown in Table 10.2 giving $10 \%$ of the sample frame. The sample size and number of questionnaire administered are presented in Table 2.

Table 2: Analysis of Selected Residential Estates and Sampling Size

\begin{tabular}{llcccc}
\hline $\begin{array}{l}\text { Name of Residential } \\
\text { Estate }\end{array}$ & Location & $\begin{array}{l}\text { No of } \\
\text { Buildings }\end{array}$ & $\begin{array}{c}\text { Existing } \\
\text { Percentage } \\
\text { Adopted }\end{array}$ & $\begin{array}{l}\text { Copies } \\
\text { Questionnaire } \\
\text { Administered }\end{array}$ \\
\hline $\begin{array}{l}\text { Adedeji Estate } \\
\text { Ademola Adesida }\end{array}$ & Akure-Ado Road & Alagbaka & 407 & 10 & 41 \\
Estate & FUTA Area & 563 & 10 & 56 \\
Alaba Layout & Ondo Road & 1052 & 10 & 105 \\
Aloba Estate & Akure-Benin & 127 & 10 & 13 \\
Gbeleaje Estate & Expressway & 428 & 10 & 43 \\
Ifelere Estate & Aule Quarters & & & 39 \\
Ire-Akari Estate & Orita Obele & 386 & 10 & 157 \\
Obele Estate & Ijare Road & 1,586 & 10 & 167 \\
Oke-Ogba Community & Agagu Road & 1,673 & 10 & 258 \\
Osolo-Abibiri Estate & Irese Road & 2,580 & 10 & 25 \\
Wesco Estate & Akure-Ilesha & 244 & 10 & 29 \\
Total & Expressway & 285 & 10 & $\mathbf{9 3 3}$ \\
\hline Source: Nationat & & & $\mathbf{1 0}$ & \\
\hline
\end{tabular}

Source: National Population Commission (1991); Field Survey, 2015

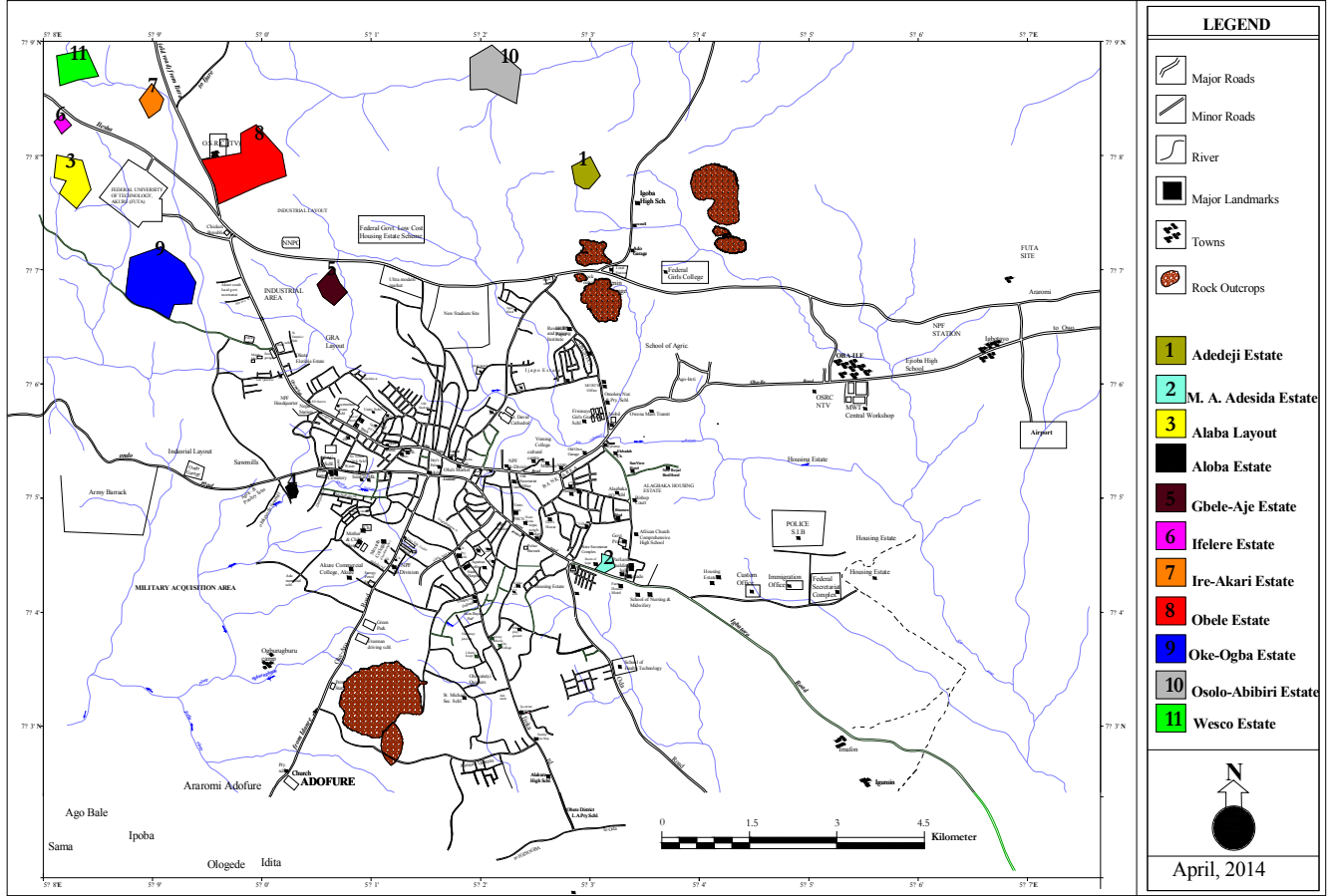

Figure 3: The Selected Eleven (11) Evolving Residential Estates in Akure

Source: Ondo State Ministry of Housing and Urban Development, 2012; Authors' Digitization, 2015

\subsection{FINDINGS AND DISCUSSION}

The socio-economic characteristics examined were; employment status, income, sex, household size, occupation status, educational status, level of car ownership and marital status. These were discussed below:

\subsection{Employment status}

Figure 4, reveals that people working in public organizations (civil servants) had the highest percentage (40.1\%) because of the proximity of the selected estates to public institutions and agencies. Next were those working in private organizations $(26.4 \%)$ which indicate that private organizations are also located close to the estates in the area. Those self-employed had 24\%, while retirees accounted for $9.6 \%$. This showed that employment status 
enhances the place of residence and reflects in density distribution (Shiller, 2007; Ilechukwu, 2010).

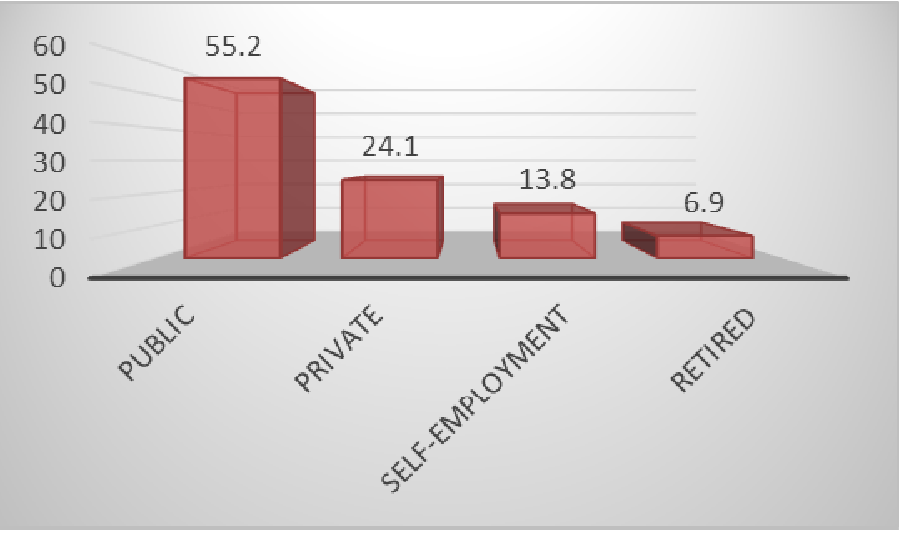

Figure 4: Employment status of respondents.

Source: Field survey, 2018

\subsection{Monthly income}

The respondents were mostly engaged in public service, judging from their levels of income. This to a large extent, determined the price an individual earmarks for housing development. The results in figure 5 indicated that majority of the residents earned between N500,000.00 and N1,000,000.00 annually. This pattern of income was spread across all the estates except Aloba estate, where majority of the respondents (46.2\%) earned below N500,000.00, Adesida and Alaba estates had majority of their respondents with annual income above $\mathrm{N} 1,000,000.00$. Majority of the respondents in Adesida Estate had higher percentage earnings due to the educational status of the people residing there, compared to other residential estates. This was in accordance with existing literature that, people with higher income live in a more decent environment (Sherri, 2006; Raji, 2008; Dosunmu, 2015).

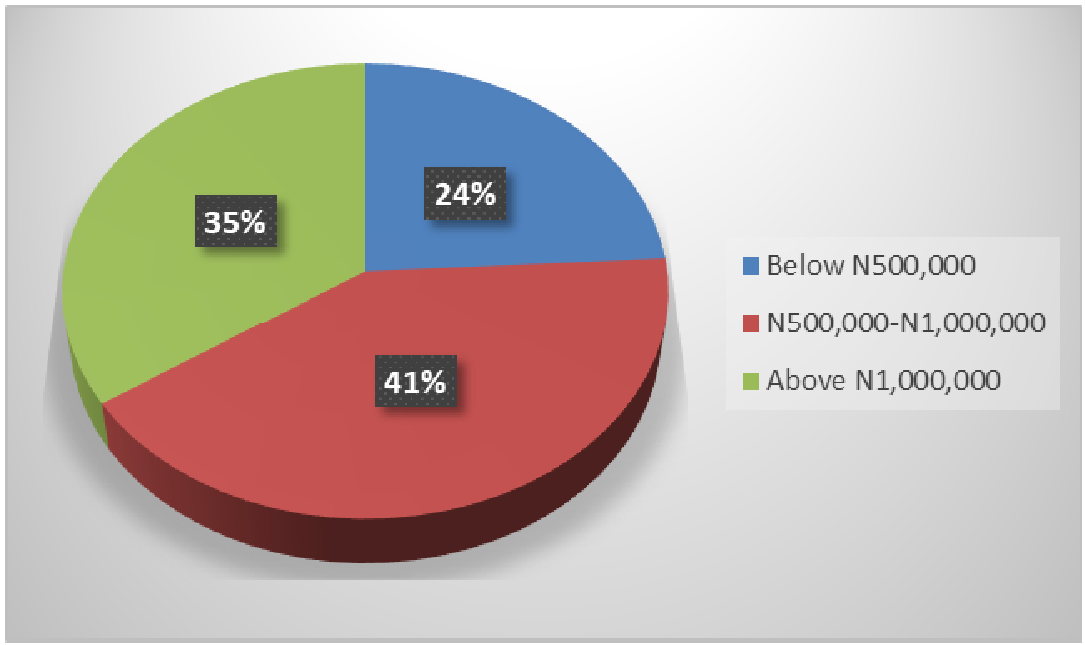

Figure 5: Monthly income of respondents Source: Field survey, 2018

\subsection{Gender}

The gender of the respondents recorded in figure 3 indicates that majority were males $(60.7 \%)$ while $39.3 \%$ were females (table 3). This was due to the fact that land ownership and housing development in the South western part of Nigeria was patrilinear (Basorun, 2015). The implication of this was that the role of males as household heads was reflected in land ownership and density distribution (Ilechukwu, 2010).

Table 3: Gender of respondents

\begin{tabular}{|c|c|c|c|}
\hline Variable & $\%$ & Fr. & $\%$ \\
\hline Male & 79.3 & 566 & 60.7 \\
\hline Female & 20.7 & 367 & 39.3 \\
\hline Total & 100 & 933 & 100 \\
\hline
\end{tabular}

Source: Field survey, 2018 


\subsection{Household size}

Most densely populated areas were dominated by large households and characterized by urban sprawl. Household size across the study area revealed that $41.9 \%$ of the residents had a household size of seven (7) and above. This was also true of areas like Aloba, Oke-Ogba and Gbeleaje Estates which had dirty and filthy environment. About $41.7 \%$ of the residents in the entire study area had a household size of 4-6 persons. This was prominent in estates such as Adedeji, Obele, Ifelere, Ire-Akari, Apatapiti, Osolo-Abibiri and Wesco. This could be attributed to the fact that these areas were inhabited mostly by middle income earners and civil servants. Those with 1-3 household size were few (16.4\%). Aloba, Gbeleaje and Oke-Ogba Estates were the most densely populated, while Adedeji, Alaba, Ifelere, Ire-Akari, Obele, Osolo-Abibiri and Wesco Estates fell in the middle density group. Adesida Estate was the only estate in the area that fell in the low density group in terms of household size.

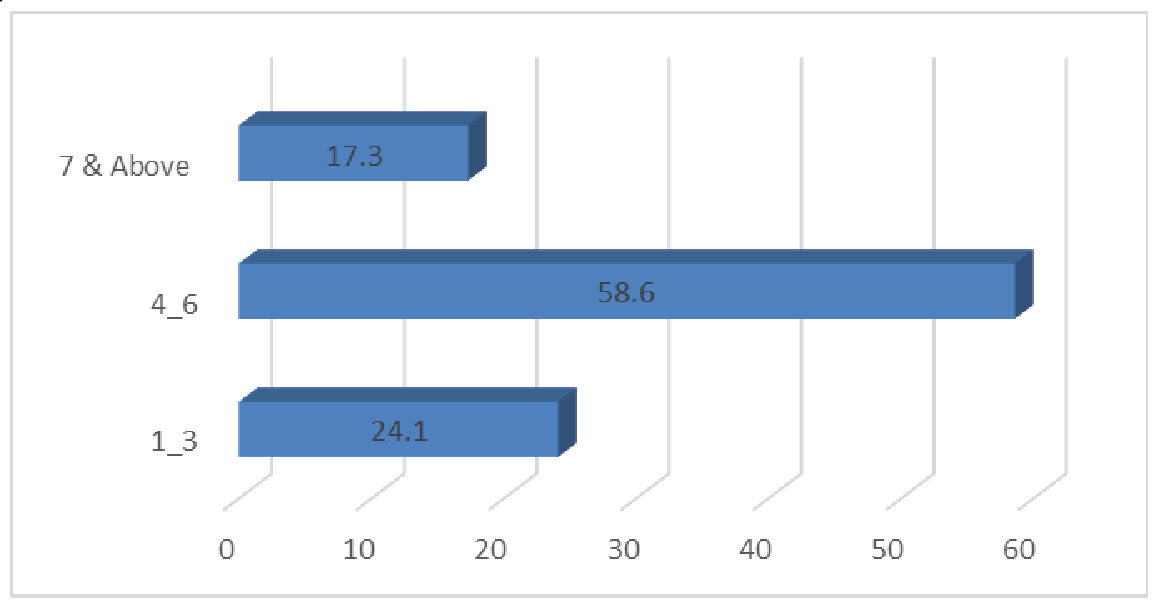

Figure 6: Household size of respondents

Source: Field survey, 2018

\section{$5.5 \quad$ Occupation}

The occupational characteristics revealed an imbalance in types and representations across the estates. From figure 7, majority of the people in Akure were civil servants $(45.2 \%)$, while craftsmen/others accounted for $28.2 \%$. Businessmen/women were 26.6 percent. Majority of the craftsmen and self-employed resided at the core and transitional zones. As observed in the study area, it shows that, occupational status of the people reflected the type and nature of buildings, as well as their density due to their income (Jinadu, 2007).

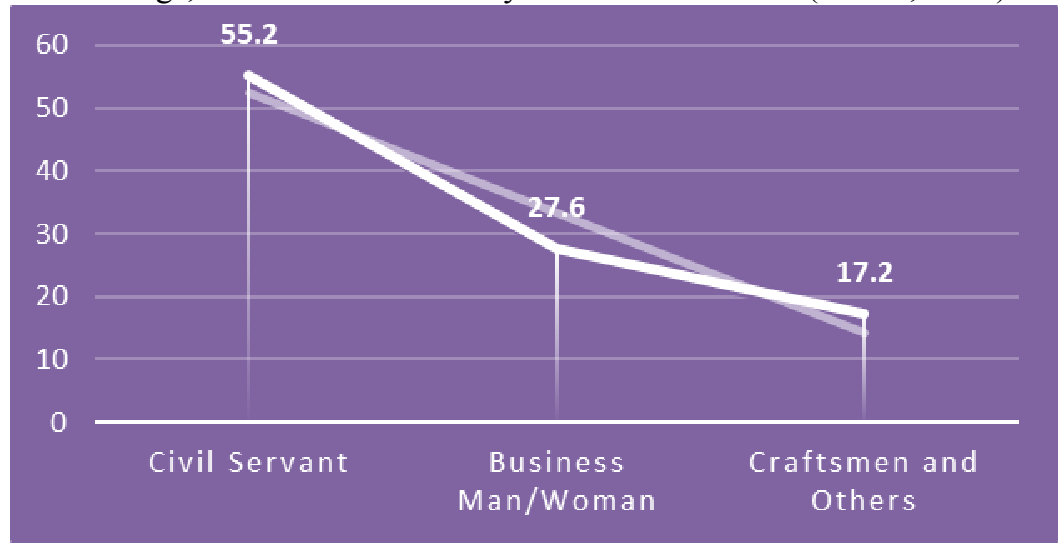

Figure 7: Occupation of respondents

Source: Field survey, 2018

\subsection{Education}

It was discovered during the survey (figure 8) that the highest level of education among the respondents was tertiary education $(35.7 \%)$, followed by secondary education $(26.2 \%)$, primary education $(17.2 \%)$, while those with postgraduate education and those without formal education were $12.3 \%$ and $8.6 \%$ respectively. The reason for the prevalence of higher education in the area was as a result of about six higher institutions located within the axis of Ondo and Ekiti State. Their level of education was reflected in their nature of employment, as majorities were civil servants (Lawanson, 2007). Larger parts of the area were categorized under the middle income level, a reflection of the employment and educational status of the residents. 


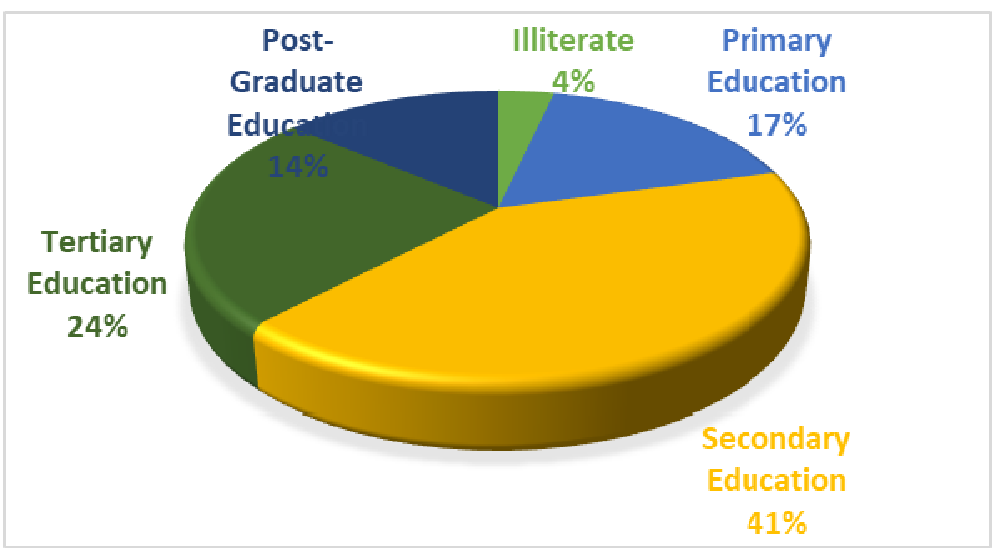

Figure 8: Education status of the residents Source: Field survey, 2018

\subsection{Car ownership}

In figure $9,32.7 \%$ of the respondents had one car, $31.1 \%$ had no car while $20.7 \%$ had two cars, $9.1 \%$ had three cars while $6.4 \%$ had above 3 cars. As expected, high income is synonymous with car ownership and better housing. High income earners as well as high literacy people tend to have more cars and live in a relatively organized low density area as reflected in the car ownership status of the residents (Mehmet, 2009).

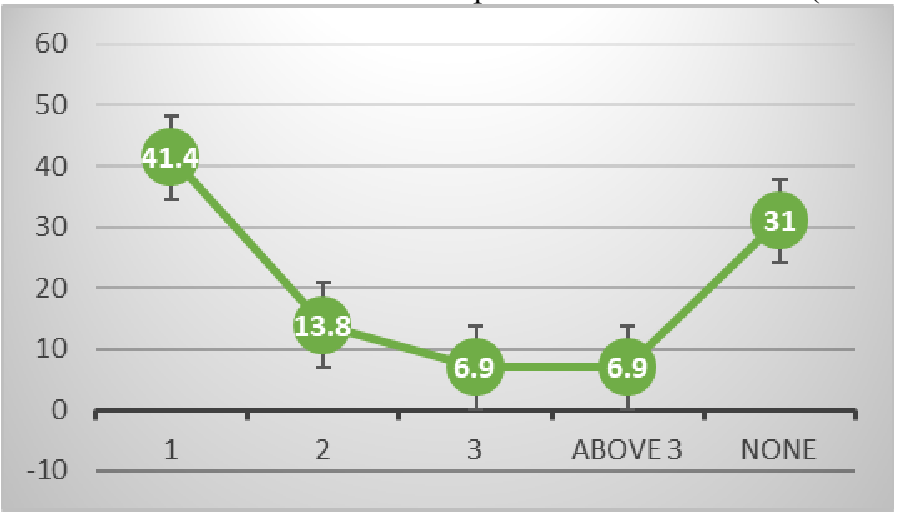

Figure 9: Car ownership status of the residents

Source: Field survey, 2015

\subsection{Marital status}

A typical Nigerian household most times, comprises of more than the nuclear family to include extended relatives. This was glaring in the nature of density observed in Akure. Almost $69.8 \%$ of the respondents were married; the percentage of those single was $13.3 \%$, while widow, divorcee and widower were $8.2 \%, 5.3 \%$ and $3.4 \%$ respectively (Table 4 ). This was because density was more associated with married people, considering the size of the household. As observed, the nature of density distribution across the study area was a reflection of the nature of respondents' marital status (Andersson, 2010).

Table 4: Marital status of respondents

\begin{tabular}{|c|c|c|c|}
\hline Variable & $\%$ & Fr. & $\%$ \\
\hline Single & 13.8 & 124 & 13.3 \\
\hline Married & 72.4 & 651 & 69.8 \\
\hline Widow & 6.9 & 77 & 8.2 \\
\hline Widower & 3.5 & 32 & 3.4 \\
\hline Divorcee & 3.5 & 49 & 5.3 \\
\hline Total & 100 & 933 & 100 \\
\hline
\end{tabular}

Source: Field survey, 2015

5.9 Relationship between socio-economic characteristics of respondents in the study area Key variables of the socio-economic characteristics of respondents related to the study were identified and isolated. These variables were paired to show any significant relationship. As a result of the heterogeneous characteristics of the variables, Spearman rho correlation was used (Table 5). The matrix indicated that, the regression results were unaffected by either pair-wise collinearity or multicollinearity. This is because there is no 
pair-wise correlation in excess of 0.70 among the independent variables (Fasakin, 2000). Variables considered were; levels of education, occupation, employment status, income and number of cars of the respondents. There was a significant relationship $(\mathrm{p} \leq 0.01)$ between occupation $(0.147)$, income $(-0.148)$, car ownership $(-0.180)$ and educational level of the respondents. This implies that, better job enhances better income and an increase in level of car ownership. There were also positive and significant relationships $(\mathrm{p} \leq 0.01)$ between employment (0.705), income (0.274), car ownership (0.109) and occupation of the respondents respectively. Public servants were the major work force with improved income of $27.4 \%$ and car ownership by $10.9 \%$. Secured job in the public sector encourages saving of money for residential development as well as ownership of cars in most urban areas in Nigeria (Akinmoladun \& Oluwoye, 2007).

Table 5: Spearman's rho correlations test on relationship among socio-economic characteristics

EDU OCCUPA EMPLOY INCOME CAR-

\begin{tabular}{llccccc}
\hline Spearman's rho & EDU & 1.000 & & & & OWN \\
& & & & & & \\
& OCCUPA & $0.147^{* *}$ & 1.000 & & & \\
& 0.000 & $\cdot$ & & & \\
& EMPLOY & 0.088 & $0.705^{* *}$ & 1.000 & & \\
& 0.080 & 0.000 &. & & \\
& INCOME & $-0.148^{* *}$ & 0.274 & 0.385 & 1.000 & \\
& 0.000 & 0.000 & 0.000 &. & 1.000 \\
& CAR-OWN & $-0.180^{* *}$ & $0.109^{* *}$ & $0.208^{* *}$ & 0.614 &. \\
\hline
\end{tabular}

**. Correlation is significant at the 0.01 level (2-tailed).

Source: Field survey, 2015

\subsection{Relationship between Socio-Economic Characteristics and Housing Density Mix in Akure}

Table 6 shows the relationship between socio-economic characteristics and housing density mix. Variables were selected to explain the relationship between socio-economic characteristics and housing density in Akure. The degree to which socio-economic characteristics of respondents impacted housing density was shown in the positive correlation coefficient $(r)=0.559$ and coefficient of determination $\left(\mathrm{R}^{2}\right)$ of 0.312 . This implies that, socio-economic variables such as level of education (EDU), occupation status (OCUPA), employment status (EMPLOY), level of income (INCOME) and level of car ownership (CAR-OWN) account for 31.2\% of housing density. Since these variables determine the status of individual in the community, everybody wants a decent and affordable housing which is one of the basic needs of individuals, the family and the community at large (Aluko, 2010).

Table 6: Model summary of relationship between socio-economic characteristics of respondents and housing density mix in the study area

\begin{tabular}{lllll}
\hline Model & R & R Square & Adjusted R Square & Std. Error of the Estimate \\
\hline 1 & 0.559 & 0.312 & 0.308 & 0.661 \\
\hline
\end{tabular}

a. Predictors: (Constant), Number of cars, Occupation, Educational level, Employment status, Income

Source: Field survey, 2015

\subsection{RECOMMENDATION AND CONCLUSION}

The study had analyzed the socio-economics implication of housing density mix in residential estates of Akure, Nigeria by assessing the socio-economic characteristics of the residents in relation to housing density mix. This was done to understand the socio-economic implication of nature and characters of residents of residential density distribution for planning attention in the city.Primary data for the study were derived from the social survey on residents. Using systematic random sampling techniques, 933 households were interviewed from a total of 9, 331 residential buildings within the study area.

Analysis of variance was used to determine the significance of the regression model regarding differences in means of the socio-economic characteristics of respondents and housing density in the study area. The ANOVA test produced an F-value of 81.98 which was significant at $\mathrm{P} \leq 0.01$. This implies that, the regression model is significant at $99 \%$ confidence level. Thus the regression model is statistically significant in predicting how socio-economic variables of education, occupation, employment, income and car ownership affect housing density. The multi-linear regression model between socio-economic characteristics of respondents and housing density revealed that education, occupation and employment had positive coefficient while income and car ownership had negative coefficient, meaning that, as some of the socio-economic variables positively impacted on housing density, others had negative impact.

In conclusion, Zoning to control residential density is the planning intervention that the city requires. 
However, this was completely missing in the time past. The initiative is inevitably left for private interest to evolve some "order of zoning" into the city. It should be noted that, residential areas designated as GRAs in the suburb of the city are low-density development by regulation. Lands were sold cheap at the beginning of development in most suburbs giving rise to high density development. There is need for diversification of economic from government oriented to private oriented. Majority of the resident were civil servant which reflect the nature of housing density in the study area, government needs to create an avenue for private investors to contribute to the economy so, that, the economic status of the residents can be uplifted. It is possible for government to also regulate access to development when approving layouts to create at least a zone of higher prices and low density. Government could resort to acquisition of vast tracts of land and pay compensation to owners to realize the goal of bringing some order to the density distribution and city form in Akure. The use of a pricing regime is the key to this development.

\section{REFERENCES}

Ajanlekoko, J. O. (2011). Construction Development Bank: A panacea for affordable housing and infrastructural development in Nigeria. A paper Delivered at the $4^{\text {th }}$ Annual Lecture of the School of Environmental Technology, Federal University of Technology, Akure, Ondo State.

Akinbamijo O. B. (2004). Environmental health and intra urban disparities - A focus on Akure. Unpublished Ph.D Thesis, Department of Urban and Regional Planning, Federal University of Technology, Akure

Akinmoladun, I. O. \& Oluwoye, J. O. (2007). An assessment of why the problems of housing shortages persist in developing countries: A case study of Lagos Metropolis, Nigeria. Pakistan Journal of Social Sciences, 4 (589-598). http://medwelljournals.com

Aluko, O. (2010). The effects of location and neighbourhood attributes on housing values in Metropolitan Lagos. Ethiopian Journal of Environmental Studies and Management. $4 \quad$ (2) 2-11. http://dx.doi.org/10.4314/ejesm.v4i2.8

Andersson, H. (2010). "Urban morphology" in Hitchison, R (Eds.), Encyclopedia of Urban Studies, (2) 8-9. Califonia, USA, SAGE Publication Inc.

Aribigbola, A. (2008). Urban land use planning, policies and management in Sub Saharan Africa. Department of Geography and Planning Sciences, Adekunle Ajasin University, Akungba Akoko

Basorun, J. O. (2015). Basic elements of urban and regional planning. Akure: Shalom Publishers

Cardew, R. (1996). Residential density in Sidney. Australian Planners, 33(2), 105-113.

Chen, J., Guo, F., \& Wu, Y. (2011). One decade of urban housing reform in China: Urban housing price dynamics and the role of migration and urbanization, 1995-2005. Habitat International, 35(1), 1-8. Retrieved February 14, 2018, from https://www.sciencedirect.com/science/article/pii/S0197397510000184

Duncan Bowie (2008). Housing delivery and sustainable communities. London: Oxford University Press

Fasakin, J. O. (2000). Willingness to pay for the service of commercial motorcycles in Akure, Nigeria. Research Note Published by Elsevier Science Limited, United Kingdom.

Fasakin, J. O., Basorun, J. O., Bello, M. O., Enisan, O. F., Ojo, B., \& Popoola, O. O. (2018). Effect of land pricing on residential density pattern in Akure, Nigeria. Advances in Social Sciences Research Journal (ASSRJ), 5(1) 31-43. Society for Science Education, United Kingdom

Gabriel, E. (2017). Spatial differentiation of housing infrastructure autonomy in Akure, Nigeria. Ph.D Thesis Submitted to the Department of Urban and Regional Planning, Federal University of Technology, Akure, Nigeria

Gebel, K. King, L., Bauman, A., Vita, P., Gill, T., Rigby, A. \& Capon, A. (2005). Creating healthy environments: A review of the links between the physical environment, physical activity and obesity. Sydney, NSW Health Department and NSW. Centre for overweight and obesity.

Ilechukwu, V. (2010). Land values and housing densities in Nigerian cities: The case of Onitsha. Urban and regional planning review, Department of urban and regional planning, University of Lagos. 1 (3), 87-94

Lawanson, O. T. (2007) Poverty and environmental degradation in the Lagos Metropolis. Journal of Environmental Science. 11 (1), 36-65

Lewyn, M. (2012). Sprawl in Canada and the United States. Social Science Research Network 44(1), 85-136

Mehmet Topçu (2009). Accessibility effect on urban land value. Scientific research and essay. 4 (11), 1286-1291, http: //www.academic journals. org/ SREISSN 1992-2248

National Population Commission [Nigeria] (2007). National Housing and Demographic Survey. Abuja, Nigeria: National Population Commission

Neptis Foundation (2014). The analysis of urban region. Neptis Nonpartisan Research, 1-7.

Nubi, O. T. (2008). Affordable housing delivery in Nigeria. The South African Foundation International conference and exhibition. Cape Town, October, 1-18.

Nwaka, G. I. (2005). The urban informal sector in Nigeria: Towards economic development, environment health and social harmony. Global Urban Development Management. 1 (1), 1-11 
Olamiju, I. O. (2014). Micro management issues in approved private residential layouts in Akure, Ondo State, Nigeria. Ph.D Thesis, Department of Urban and Regional Planning, Federal University of Technology, Akure.

Omole F.K (2001). Basic issues in housing development. Akure: Femobless Publishers

Omole, F. K. (1999). Planning issues in Nigeria: Land tenure system and land use act. Lagos: Frontline Publication Limited.

Omole, F. K. (2012). An assessment of housing condition and socio-economic life styles of slum dwellers in Akure, Nigeria. Contemporary Management Research, 6(4), 273-270

Omole F. K. \& Akinbamijo O. B. (2012). Land development and planning laws in Nigeria: The historical account. Journal of Law, Policy and Globalization. ISSN 2224-3240 (Paper) ISSN 2224-3259 (Online). 8. www.iiste.org

Ondo State Government (1990). Digest of demographic Statistics of Ondo State. Ministry of Finance, Budget and Planning, Akure

Owoeye, J.O. (2016). Analysis of Akure urban land use change detection from remote imagery perspective. Urban Studies Research. Article ID:4673019: 1-9; Hindawi Publishing Corporation

Raji, O. (2008). Public and private developers as agents in urban housing delivery in Sub Saharan Africa: The Situation in Lagos State. Humanity of Social Sciences Journal, 3 (2), 143-150.

Rotowa, O. O. (2014). Spatio-environmental management of faecal waste in residential zones of Akure, Nigeria. Ph.D Thesis Submitted to the Department of Urban and Regional Planning, Federal University of Technology, Akure, Nigeria

Schulz, M. A. Werwatz, A. (2004). A state space model for berlin house price: estimation and economic interpretation. Journal of real estate finance and economics, 28 (1), 37-57

Sherri, L. J. (2006). Research Methods and Statistics. USA: Thomason Windsworth. Second Edition

Shiller, R. J. (2007). Understanding recent trends in house price and home ownership. Paper presented at Federal Reserve Bank of Kansa City conference at Jackson Hole, August 31 